\title{
Gibbs による界面熱力学の考え方
}

西岡 一 水*

$\mathrm{Gibbs}^{(1)}$ との出会いは,今から 20 年近く前 Stan一 ford に打けるPoundの核生成理論に関する講義 の中で今だに登頂を許さずそびえ立つ熱力学の巨 峰として畏敬の念をこめて紹介された時にさかの ぼる。熱力学の普遍性と䈯密さとに強くひかれて いた筆者は早速その攻略にと取り掛かったが, 要求される極度の精神集中に耐えながらこれまで に触れえたのは論文の 2 割にも足りない 50 ペー ジ程にすぎない。それでも，Gibbs 以降数多く書か れた名著といわれる書物も 100 年以上前の Gibbs の原典には遠く及ばないといら Pound の言葉を理 解するには十分であった。 Gibbs 特有の抽象性と 一語一句に至るまで深い含みのある簡潔な表現の もたらす難解さの故もあってかあまり読まれるこ ともなく半ば歴史上の古典視されている原典は, 熱力学の基礎打よび応用に和ける本質的な概念に 関して今だに最も新しい論文と言えるのではなか ろらか、ここでは, 筆者が触れえたものの中から 表面張力と臨界核生成可逆仕事との概念について の解説を試みるが，非才から Gibbs の考え方を正 しく伝えていないことも十分考觉られることを拉 断りし，読者が自分で原典に触れられることを拉 勧めしたい。原典の理解を助ける目的で書かれた 解説として著名なもの ${ }^{(2)}$ があるので，本解説と合 わせて参考にされると良いと思ら。

\section{界面の熱力学}

\section{分割面と仮想系}

もともと熱力学は巨視的な系を考察の対象と

* 德島大学教授; 工学部

Gibbs' Method of the Thermodynamics of Interface ; Kazumi Nishioka(Faculty of Eng., The Univ. of Tokushima, Tokushima)

Keywords : thermodynamics, interface, surface tension. Gibbs, dividing surface, surface of tension, critical nucleus, nucleation, liquid microcluster. reversible work \begin{tabular}{l}
1986 年 4 月 2 日受理 \\
\hline
\end{tabular}
し，系の境界の影響は無視できるものとの前提の もとで熱力学变数は示量変数と示強变数とに分 類される。この事情は系が共存する 2 相から成る 場合にも同様であって，例えば相律に打いてそう であるように，両相それぞれの巨視的諸量が考察 の対象となり界面の性質自身は表に現われない. ところが，界面の性質そのものが考察の対象とな る場合とか核生成現象を扱う場合には, 界面の性 質を取り入れた形に熱力学を拡張する必要が生じ る。ここでは流体相の界面に限定して $\mathrm{Gibbs}^{(3)}$ に 従って界面の熱力学についての考察をすすめる.

図 1 に示す様に流体相 $\alpha, \beta$ が界面を介して共存 し平衡状態にあるとする。簡単のため重力の影響 は考えない，分子間相互作用の及ぶ範囲は短いの で，互いに隣接する相の影響は破線で示す様に界 面のごく近傍に限られると考えて良い，界面の近 傍では均一でないため界面の位置を確定すること ができないが，分割面 Sを導入することによって 界面の確定した位置を定義する。例えば微小液滴 と蒸気との界面に招いては不均一な領域の厚さが 液滴のサイズと同程度となることも考えられ，従 って液滴の径は明確でなくなるが，この場合にも 分割面の径は確定する。分割面の位置を決める方 法とか界面の熱力学的性質を分割面のもつ性質と して抽象化してゆく方法について以下に考光てゆ

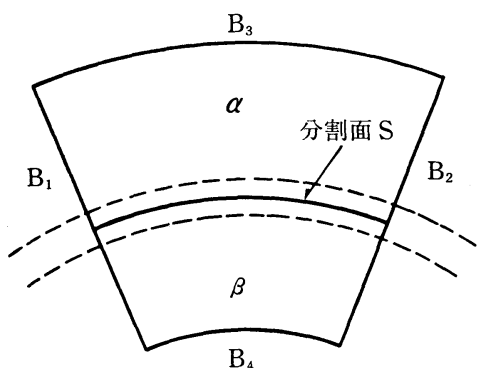

図 1 界面に打ける不均一領域と分割面. 
くわけであるが，この分割面のもつ抽象性が界面 熱力学の理解を困難にする所以である.

$\mathrm{S}$ 飞垂直飞仮想境界 $\mathrm{B}_{1}, \mathrm{~B}_{2}$ をとり，均一な $\alpha$ 相, $\beta$ 相を通る位置に仮想境界 $\mathrm{B}_{3}, \mathrm{~B}_{4}$ をとる。 こ れらの仮想境界で囲まれた部分を系としてこの系 に属する種々の熱力学量を考えるわけであるが, 体積とか物質量 $m_{\mathrm{i}}$ は確定するとしても, 内部エネ

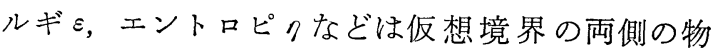
質の相互作用の效果を含むので単純には定まらな い.しかしながら仮想境界に垂直な方向には均一 であるから，相互作用の效果は境界の両側に等分 配されると考えることができ従って系のエネルギ およびェントロピも確定する。

物質量 $m_{\mathbf{i}}$ はすべての成分について独立に変觉 らるとすると, 境界固定のもとでの系の状態の微 小変分に対して次式が成立する。

$$
\delta \varepsilon=t \delta \eta+\Sigma \mu_{\mathrm{i}} \delta m_{\mathbf{i}}
$$

温度 $t$, 化学ポテンシャル $\mu_{\mathrm{i}}$ が仮想境界の内外に わたって均一であることの証明には複雑な考察が 必要であるが，ここではそれを認めることにする と, 式（1）は仮想境界の内部拈よび外部のすべて を含む巨視的系に対して同様な式が成立すること からその成立が理解される。式（1）の成立にあた って変分を加える前は平衡状態にある必要がある が微小変分を加えた後の状態は必ずしも平衡にあ る必要はない。

界面の熱力学的性質を分割面の性質として定式 化してゅく過程で次に導入される概念が仮想系 の概念である. 図 1 に打いて，S の両側の領域が それぞれその側のバルク相によってSまで満たさ れている系を考える。すなわち， $\alpha$ 相の領域はS を越えた領域にも均一なバルク $\alpha$ 相が存在してい るかの様な性質をもつものとし， $\beta$ 相についても 同様とする。すなわち，仮想系に执いてはSを隔 てた両側の領域は各々巨視的なバルク相の一部と しての性質をもつものとする。従ってその内部土 ネルギ $\varepsilon^{\alpha}, \varepsilon^{\beta}$, エントロピ $\eta^{\alpha}, \eta^{\beta}$ および物質量 $m_{\mathrm{i}}^{\alpha}$, $m_{\mathrm{i}}^{\beta}$ の変分はバルク相に対して成立する式を満た 于.

$$
\begin{aligned}
& \delta \varepsilon^{\alpha}=t \delta \eta^{\alpha}+\Sigma \mu_{\mathrm{i}} \delta m_{\mathrm{i}}^{\alpha} \\
& \delta \varepsilon^{\beta}=t \delta \eta^{\beta}+\Sigma \mu_{\mathrm{i}} \delta m_{\mathrm{i}}^{\beta}
\end{aligned}
$$

$\dagger$ この名称はGibbsによるものではないが, その抽象 性を表わすためこう呼ぶことにする。
ただし仮想境界および分割面は固定されていると した.

エネルギ，エントロピおよび物質量について実 際の系の值と仮想系の值との差は界面の存在に結 びつけられ， $\varepsilon^{\mathrm{s}}, \eta^{\mathrm{s}}$ および $m_{\mathrm{i}}^{\mathrm{s}}$ と書くことにする. すなわち

$$
\left.\begin{array}{l}
\varepsilon^{\mathrm{s}}=\varepsilon-\varepsilon^{\alpha}-\varepsilon^{\beta}, \eta^{\mathrm{s}}=\eta-\eta^{\alpha}-\eta^{\beta} \\
m_{\mathrm{i}}^{\mathrm{s}}=m_{\mathrm{i}}-m_{\mathrm{i}}^{\alpha}-m_{\mathrm{i}}^{\beta}
\end{array}\right\}
$$

式 (1)〜（4)より次式を得る.

$$
\delta \varepsilon^{\mathrm{s}}=t \delta \eta^{\mathrm{s}}+\Sigma \mu_{\mathrm{i}} \delta m_{\mathrm{i}}^{\mathrm{s}}
$$

界面を含む実際の系と仮想系との関係をより分か りやすく示したのが図 2 である。

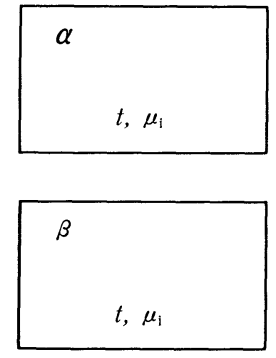

仮想系

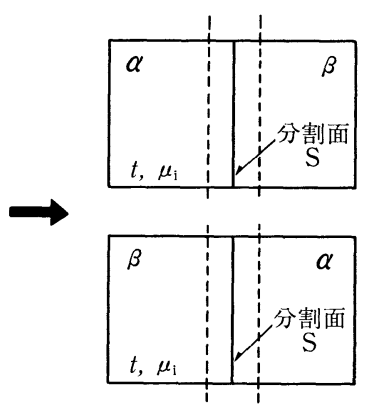

界面を含む系
図2 界面を含む系と仮想系との関係。

\section{張力面と表面張力}

式（5）を導くにあたっては図１において仮想境 界および分割面を固定した条件のもとでの変分を 考えたが，次にこの条件をとり去った際に式（5) に加えられる項について考觉よう。均一な相を通 過している仮想境界の変分は, 式 (1) 打よび式 （2），(3) 飞同一の寄与をするため式（5)には影 響しないので, 分割面の面積および形状の変分を 考えればよい。まず形状不変のままで面積の変分 を考えよう。その際，仮想境界 $\mathrm{B}_{1}$ または $\mathrm{B}_{2}$ の移 動を伴らため, 式 (1)の右辺には一種の仕事の項 $\delta W$ が加わる. この変分に対応する仮想系の変分 はバルク相に対する体積の变分 $\delta v^{\alpha}$ 打よび $\delta v^{\beta}$ と なるから, 式 (2)，(3)には単に $-p^{\alpha} \delta v^{\alpha},-p^{\beta} \delta v^{\beta}$ が加わるにすぎない。よって, 式 (5)の右辺には 分割面の面積の変分 $\delta s$ に伴って $\delta W-\left(-p^{\alpha} \delta v^{\alpha}-\right.$

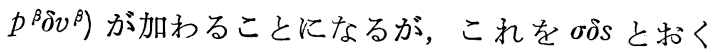
ことによって $\sigma$ なる量を導入する。すなおち,

$$
\sigma \delta s=\delta W-\left(-p^{\alpha} \delta v^{\alpha}-p^{\beta} \delta v^{\beta}\right)
$$

従って, 式 (5) は次式となる. 


$$
\delta \varepsilon^{\mathrm{s}}=t \delta \eta^{\mathrm{s}}+\Sigma \mu_{\mathrm{i}} \delta m_{\mathrm{i}}^{\mathrm{s}}+\sigma \delta s
$$

实際の系に対する仕事の項 $\delta W$ には界面近傍の 不均一性が複雑に影響するため，これを直接簡単 な式で表わすことは望めないが，熱力学の立場と しては何とか実測可能な量を用いてこれを表わ し，さらにその量を他の熱力学量と関連づけたい わけである. Gibbs の方法は式 (6)に示されるよ らに $\delta W$ と良くわかったバルクの量である仮想系

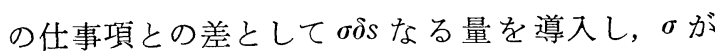
実測可能となることを期待していることになる. $\delta s$ は分割面の面積の変分であるから, 実際の界面 に対する項 $\delta W$ を抽象的な分割面の量 $\sigma \delta s$ へとバ ルク相の性質の助けをかりて拉きかえていると言 っても良い。このよらに界面の存在による效果を 仮想系の性質との差によって表わすのは図 2 から も納得できる方法である。

最後に，分割面の形状の変分を考える，系は平 衡状態にあるとしているので分割面の形としては 球面を仮定し, 変分としてその曲率 $c$ の変分 $\delta c$ を とることにすると，式（7)の右辺にC $C \delta c$ が加えら れる。すなわち, 分割面に付随して次式がえられ る.

$$
\delta \varepsilon^{\mathrm{s}}=t \delta \eta^{\mathrm{s}}+\Sigma \mu_{\mathrm{i}} \delta m_{\mathrm{i}}^{\mathrm{s}}+\sigma \delta s+C \delta c
$$

曲率が変わると界面に和ける分子の分布の様子が 変わると考えられることから曲率の項の必要性が 理解できる。

これまで分割面についてはある決め方によって その位置を確定できるものと考えてきたが，その 具体的な決め方については保留してきた。 その決 め方については任意性があるが，ここでは式 (8) にお壮る曲率の項の係数 $C$ が零となる位置に選定 する。この位置に選ばれた分割面は張力面と呼ば れ， $\sigma$ が力学的張力として測定されらる量となる ことに密接に関係している。よって, 張力面に対 して次式が成立する。

$$
\delta \varepsilon^{\mathrm{s}}=t \delta \eta^{\mathrm{s}}+\Sigma \mu_{\mathrm{i}} \delta m_{\mathrm{i}}^{\mathrm{s}}+\sigma \delta s
$$

張力面の位置に分割面を選ぶことが常に可能であ り，かつそれが物理的界面の不均一領域内に位置 することがGibbsによって考察されている。

上述のように図 1 の系に対して界面の変分をも 考虑に入れると次式が成立する.

$$
\delta \varepsilon=t \delta \eta+\Sigma \mu_{\mathrm{i}} \delta m_{\mathrm{i}}+\sigma d s-p^{\alpha} \delta v^{\alpha}-p^{\beta} \delta v^{\beta}
$$

系が平衡状態にあるための条件は, 熱力学第 2 法 則によって

$$
\delta \varepsilon)_{\eta, m_{\mathrm{i}}, \text { boundary }}=0
$$

で与えられ，これを式(10)に適用すると

$$
\sigma \delta s-p^{\alpha} \delta v^{\alpha}-p^{\beta} \delta v^{\beta}=0
$$

を得る、ただし，界面の変分を考兵るに際しては 図 1 の仮想境界 $\mathrm{B}_{1} \sim \mathrm{B}_{4}$ は固定されているとの条 件が課されるので, 変分としては張力面のそれに 垂直な方向への移動 $\delta l$ をとる式 (12) より次の結 果を得る。

$$
p^{\beta}-p^{\alpha}=2 \sigma / R
$$

ただし $\alpha$ 相は界面の凸側の相とし $\beta$ 相は凹側とす る。また $R$ は張力面の半径である.

式(13)は張力面の位置にとられた分割面を張力 $\sigma$ をるち剛性のない膜とみなしたときの力学的つ り合いの式であり， $\sigma$ の值を力学的方法によって 実測しらることを意味する。この理由により $\sigma$ は 表面張力と呼ばれる。式(13)が成立するのは分割 面として張力面を選んだ場合に限られるが，巨視 的な系では界面での不均一領域の厚さは $R$ に比べ て無視できるので, 張力面の径は事実上界面の曲 率半径として実測されらる。このよらにして, 界 面の面積の変分に伴ら複雑な仕事の項 $\delta W$ を視 的方法によって実測可能な量 $\sigma$ を用いて表わすこ とができたわけである。

式 (9) は平衡状態にある系に対して加えられる 任意の変分について成立し, 変分の加わった状態 は必ずしも平衡状態である必要はない。微小変化 を生じた後も系が 平衡状態にある場合には微小変 化を表わすのに $\delta$ の代りにdを用いることにする と

$$
d \varepsilon^{\mathrm{s}}=t d \eta^{\mathrm{s}}+\Sigma \mu_{\mathrm{i}} d m_{\mathrm{i}}^{\mathrm{s}}+\sigma d s
$$

がえられる，界面に沿って均一な性質をもつとし て, 式(14)を張力面の面積零から $s$ まで積分する と

$$
\varepsilon^{\mathrm{s}}=t \eta^{\mathrm{s}}+\Sigma \mu_{\mathrm{i}} m_{\mathrm{i}}^{\mathrm{s}}+\sigma s
$$

を得る。これはバルク相に対して成立する式

$$
\begin{aligned}
& \varepsilon^{\alpha}=t \eta^{\alpha}+\Sigma \mu_{\mathrm{i}} m_{\mathrm{i}}^{\alpha}-p^{\alpha} v^{\alpha} \\
& \varepsilon^{\beta}=t \eta^{\beta}+\Sigma \mu_{\mathrm{i}} m_{\mathrm{i}}^{\beta}-p^{\beta} v^{\beta}
\end{aligned}
$$

と類似の式である.

\section{微小系について}

過飽和蒸気中に生成する液相臨界核の様に一方 


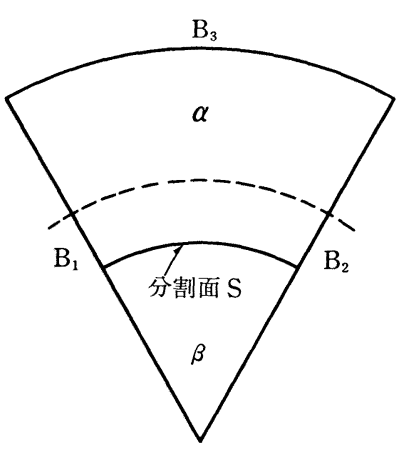

図 3 微小系の界面.

の相が微小な場合を次に考学る。この場合には図 3 に示寸系について考光るとよい(4). $\mathrm{B}_{1} \sim \mathrm{B}_{3}$ は仮 想境界を示し，破線の内側が不均一な領域を示 す。液滴は球形とし，その中心部においてもバル ク $\beta$ 相の均一な性質に達しない程に微小とする. この場合にも図 1 の系と同様な考察によって張力 面を分割面として式 (9)，(13) 和よび(15)などが 得られる。式(13)において $p^{\beta}$ は仮想系の圧力で あるから，微小液滴中心部の圧力ではなく $\alpha$ 相と 同一の温度と化学ポテンシャルを持つバルク $\beta$ 相 の圧力を意味することには注意を要する。微小系 の表面張力 $\sigma$ の值は巨視的な $\beta$ 相に対して実測さ れたものとは異なる可能性がある(4).

\section{臨界核生成可逆仕事}

図 4 亿示すように巨視的な $\alpha$ 相の内部に微小な $\beta$ 相が生成するといら核生成の問題では, 界面の 考察が主要な地位を占める。系は平衡にあると し, 従って温度 $t$ 和よび化学ポテンシャル $\mu_{\mathrm{i}}$ は均 一であるとする。すなわち， $\alpha$ 相中に $\beta$ 相の臨界 核が存在する系を考察する。 $\beta$ 相を球形とすると 式(13) が成立する。

均一な $\alpha$ 相の内部にそれと平衡状態にある $\beta$ 相 を生成するに要する可逆仕事 $W^{\mathrm{rev}}$ は, 全系の土 ントロピ, 物質量および体積不変のもとでの内部

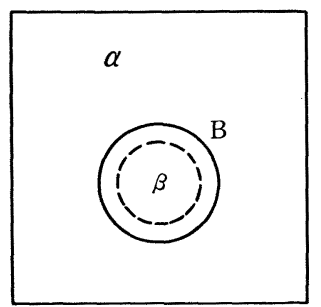

図 4

$\alpha$ 相中に生成した $\beta$ 相臨界核.
エネルギの増分によって与えられる，図４の実線 で示すよらに $\beta$ 相を囲み均一な $\alpha$ 相を通る仮想境 界 Bを考光，この内部のエネルギ，エントロピ抒 よび物質量の $\beta$ 相生成前後に拈ける差を $[\varepsilon],[\eta]$ および $\left[m_{\mathbf{i}}\right]$ とすると，全系のエントロピおよび 物質量を不変とすればー $[\eta]$ 打よび $-\left[m_{\mathrm{i}}\right]$ は仮 想境界 Bの外部での変化量を表わす。 $\alpha$ 相は巨視 的であり， $\beta$ 相生成による $t, \mu_{\mathrm{i}}$ の変化を無視でき るとすれば，体積一定のもとで成立する式

$$
d \varepsilon^{\alpha}=t d \eta^{\alpha}+\Sigma \mu_{\mathrm{i}} d m_{\mathrm{i}}^{\alpha}
$$

より $-t[\eta]-\Sigma \mu_{\mathrm{i}}\left[m_{\mathrm{i}}\right]$ は仮想境界 Bの外部でのエ ネルギ増分を与え, 従って $W^{\mathrm{rev}}$ は次式によって 与朰れる。

$$
W^{\mathrm{rev}}=[\varepsilon]-t[\eta]-\Sigma \mu_{\mathrm{i}}\left[m_{\mathrm{i}}\right]
$$

$[\varepsilon],[\eta]$ 打よび $\left[m_{\mathrm{i}}\right]$ の意味と $\varepsilon^{\mathrm{s}}, \eta^{\mathrm{s}}$ 打よび $m_{\mathrm{i}}^{\mathrm{s}}$ の 意味とを考えあわせ，式(15)〜（17）を考慮に入れ ると式(19)は次のように変形される。

$$
W^{\mathrm{rev}}=\sigma s-v^{\beta}\left(p^{\beta}-p^{\alpha}\right)
$$

ただし $s$ は $\beta$ 相臨界核の張力面の面積, $v^{\beta}$ は張力 面内部の体積を表わす。結局, 臨界核生成可逆仕 事は式 (20)によって与えられることがわかる(5).

式 (20)の右辺第 1 項㘧よび第 2 項の意味をより 明白にするため Gibbs に従って以下の可逆過程を 考える.図 5 に示すように $\alpha$ 相の内部に巨視的な $\beta$ 相が存在するとし, 圧力差を保つために $\beta$ 相は膜 で扮拈われ可逆仕事源によって圧力 $p^{\beta}-p^{\alpha}$ が及 ぼされているとする。この膜は自由に物質を通す 性質をもち，系は平衡にあるとする。この膜を通 $し て \alpha$ 相から $\beta$ 相へと可逆的に物質を移し, $\beta$ 相 の体積を列だけ増加させる.両相に颃いて化学ポ テンシャルは等しく，また $\beta$ 相は巨視的であるか らこの体積增加に伴う表面積の増加は無視でき, 従ってこの過程に要する可逆仕事は $-v^{\beta}\left(p^{\beta}-p^{\alpha}\right)$ となり式(20)の第 2 項がえられる。

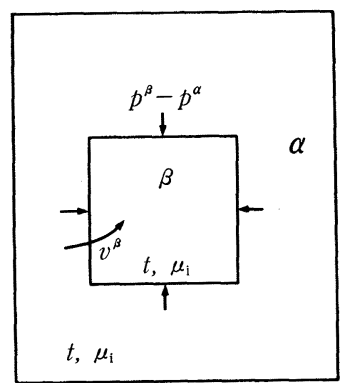

図 5 臨界核生成可逆仕事に打けるバルク項の意味. 


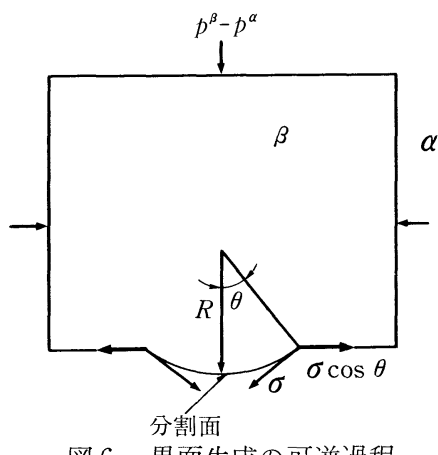

図 6 界面生成の可逆過程。

次に, 図6に示すように, $\beta$ 相を $\alpha$ 相の中に $v^{\beta}$ の量だけ可逆的に押し出すために $\beta$ 相を包む膜に 小さな孔をあけそして閉じる過程を考学る。物理 的には無論分子の不均一分布を伴ら界面が生じる が，既述のようにこれは張力 $\sigma$ を有する張力面之 その両側をみたすバルク相とでおきかえられる。 図 6 に示すように孔のらちに $\sigma \cos \theta$ なる力を可 逆仕事源によって及涪せば，式(13)によって系は 平衡にあことがわかる。よって, 張力面の半径 $R$ をひ $\beta$ 相を可逆的に押し出すに際して，孔の
らちに拈いてなされる仕事は $4 \pi R^{2} \sigma / 3$ と計算さ れ，膜を押すに要する仕事は $v^{\beta}\left(p^{\beta}-p^{\alpha}\right)$ となる。 この和が界面生成に要した可逆仕事であり，式 (13)を用いると $\sigma s / 3+v^{\beta}\left(p^{\beta}-p^{\alpha}\right)=\sigma s$ となって式 (20)の第 1 項を得る.

以上の考察によって式 (20) 第 1 項の界面生成仕 事の意味および第 2 項のバルク仕事の 意味が明ら かになった。同じ $t, \mu_{\mathrm{i}}$ を有するバルク相について $p^{\beta}>p^{\alpha}$ が成立するときに限り $\alpha$ 相から $\beta$ 相への 相変態が可能であることがわかる。ゆらぎの熱力 学により核生成頻度は $\exp \left(-W^{\mathrm{rev}} / k t\right)$ に比例す $ろ^{(6)}$.

\section{文献}

(1) J.W.Gibbs: The Scientific Papers of J. Willard Gibbs, Vol.I, Dover, New York, (1961), p.55-349.

(2) J.Rice: A Commentary on the Scientific Writings of $J$. Willard Gibbs, Vol.I, Ed. by F.G.Donnan and A.Haas, Yale Univ. Press, New Haven, (1936), p.505-708.

(3) 文献( 1 ), p.219-237.

(4) K.Nishioka, Phys. Rev. A, 16(1977), 2143.

(5) 文献( 1 ), p.252-258.

（6）西岡一水: 日本物理学会誌, 30(1975), 116.

<新 刊案 内>

\section{The Making, Shaping and Treating of Steel 10th Edition/Latest Technology \\ W.T.Lankford, Jr., N.L.Samways, R.F.Craven, H.E.McGannon 編}

本書は 1919 年に初版が刊行されて以来，すでに 23 万部以上出版され，鉄鋼関連の技術者，研究者に広く 読まれてきた “鉄鋼のバイブル” のような著名な書物 である.今回は第 10 版の改訂版で U.S.Steel 社の約 60 名の研究者, 技術者によって書かれたものを AISE (Association of Iron and Steel Engineers)から 出版されたものである.

1971 年の第 9 版が出版されて以来, 鉄鋼業をめぐ る情勢は第 3 世界に扔ける工業化，1973年の石油危 機による省エネルギー，環境改善と大きく変わってお り，大幅な増補改訂が加えられて今回第 10 版が出版 された

その内容は書名の示すとおり，鉄鋼に関する最新の 技術ならびに学術の実際面に役立つ資料を集大成した あので，鉄鋼技術全般を総合的体系的に集録したもの である. 第 9 版と比べて新しく 2 次精錬，連続鋳造の 2 章が加えられ全章 53 章から成り立って扔り, 1984 年までの新しい文献が引用されている.日本鉄鋼協会 の鉄鋼便覧之同類の内容の書物であるが，現場技術の
写真が多く引用されており，図もわかりやすく説明さ れている.

内容は膨大なので簡単に書けないが，耐火物，原燃 料, 選鉱, フラックス, スラグ, スクラップ, フェロ アロイ, 製銑製鋼法押よびその物理化学, 直接製鉄, 溶融還元，電気炉製鋼法，2次精錬，凝固，連続鋳造， 塑性加工, 鉄鋼材料, 鋼板, 条鋼, 線材, 冷熱間圧延, 腐食防食, 表面処理, めっき, 鍛造, 鋳造, 熱処理, 構造, 耐熱鋼, 高張力鋼, ステンレス鋼, 鋼材の評価 法, 各種試験法, 切削性等である.

個人で所蔵するような書物ではないが，鉄鋼に携わ る技術者, 研究者にとって, 又, 関連の産業界の方々 にあ十分活用できる書物である. 第 9 版よりも新しい データが引用され内容む書き変えられているので鉄鋼 を扱う諸会社, 研究者, 大学に備えておくことは意味 のあることである.

$〔 19 \times 27.5 \mathrm{~cm} \quad 1572$ 頁 1985 年 US $\$ 125.00$

Association of Iron and Steel Engineers : Suite 2350, Three Gateway Center, Pittsburgh, Pennsylvania, USA] 